\title{
Hemophagocytic Lymphohistiocytosis Disease Mimic Due to Brucellosis
}

Andrea A. Hauser, MD ${ }^{1,2}$ - Kylie S. Durand, MD ${ }^{1,2}$ - Ankhi Dutta, MD, MPH ${ }^{2,3}$

A previously healthy and fully vaccinated 3-year-old girl was brought to our emergency department (ED) with a 7-day history of daily fever (up to $40^{\circ} \mathrm{C}$, axillary), a rash on her face and extremities, peeling of the soles of her feet, and intermittent nonbloody, nonbilious emesis.

\section{History}

The patient's mother denied the patient had cough, congestion, shortness of breath, abdominal pain, diarrhea, swelling of hands and feet, mucous membrane changes, conjunctival injection, or dysuria. There had been no recent travel, sick contacts, or known exposure to COVID-19. The patient lived in Houston, Texas, with her mother and did not attend daycare. There was no history of pets or animal exposures.

The patient had been initially evaluated at an outside hospital, where she had a normal white blood cell count, a low platelet count, a mildly low hemoglobin level, an elevated liver enzyme level, an elevated D-dimer level, an elevated lactic dehydrogenase level, an elevated C-reactive protein (CRP) level, and an

\section{AFFILIATIONS:}

'Section of Pediatric Hospital Medicine, Texas Children's Hospital and Baylor College of Medicine, Houston, Texas

${ }^{2}$ Department of Pediatrics, Texas Children's Hospital and Baylor College of Medicine, Houston, Texas ${ }^{3}$ Section of Infectious Diseases, Texas Children's Hospital and Baylor College of Medicine, Houston, Texas

\section{CITATION:}

Hauser AA, Durand KS, Dutta A. Hemophagocytic lymphohistiocytosis disease mimic due to brucellosis. Consultant. Published online February 16, 2022. doi:10.25270/con.2022.02.00006

Received August 18, 2021. Accepted September 3, 2021.

\section{DISCLOSURES:}

The authors report no relevant financial relationships.

\section{CORRESPONDENCE:}

Andrea Hauser, MD, Texas Children's Hospital, 1102 Bates Avenue, Suite 1860, Houston, TX 77030 (aahauser@texaschildrens.org) elevated ferritin level. Results of basic blood chemistry panels, a urinalysis, and tests for troponin and brain natriuretic peptide were within normal limits. Results of a respiratory viral polymerase chain reaction (PCR) panel, monospot test, and rapid streptococcal antigen test were negative, and a chest radiograph was unremarkable. Blood and urine cultures were collected and sent for evaluation. The patient was transferred to our ED for further evaluation and management.

\section{Physical Examination}

Upon arrival to our ED, the patient was febrile with a temperature of $40.5^{\circ} \mathrm{C}$ (axillary), irritable, and tachycardic but nontoxic appearing. She had mild conjunctival injection without drainage; a macular, erythematous rash on her face and extremities; a rash involving the soles of her feet with mild desquamation; and a faint petechial rash over the abdomen. She had no lymphadenopathy and no palpable hepatosplenomegaly. The remainder of her physical examination was unremarkable.

\section{Diagnostic Testing}

Given the broad differential diagnosisespecially during the COVID-19 pandemic-an infectious disease specialist, rheumatologist, and cardiologist were consulted. The differential diagnosis included COVID-19, multisystem inflammatory syndrome in children (MIS-C) triggered by SARS-CoV-2, and incomplete Kawasaki disease. Other infectious etiologies such as occult bacteremia, evolving toxic shock syndrome, viral sepsis (ie, cytomegalovirus, Epstein-Barr virus, adenovirus, parvovirus), rickettsial illness, and ehrlichiosis were also considered.

Repeat blood and urine cultures were collected. Intravenous doxycycline, 2.2 $\mathrm{mg} / \mathrm{kg}$ every 12 hours was empirically started for suspected murine typhus due to endemicity in the Houston area. Results of a SARS-CoV-2 PCR test were negative, and a SARS-CoV-2 antibody titer was nonreactive. An echocardiography scan was conducted for suspicion for Kawasaki disease and MIS-C, results of which showed normal function and trivial mitral regurgitation without coronary artery dilatation.

On hospital day 2, the patient continued to be febrile (day 9 of fever). A repeat echocardiography scan was conducted but results of which were unchanged. Empiric intravenous ceftriaxone, $50 \mathrm{mg} /$ kg every 24 hours was added while results of the blood and urine cultures were pending. After a multidisciplinary discussion on hospital day 3 , it was determined that the patient met criteria for incomplete Kawasaki disease, thus intravenous immunoglobulin (IVIG), $2 \mathrm{~g} /$ $\mathrm{kg}$ and aspirin, $5.5 \mathrm{mg} / \mathrm{kg} / \mathrm{d}$ were started.

The blood culture obtained on hospital day 1 returned positive results for Gram-negative rods, and the urine 


\section{Table 1. Diagnostic Criteria for Hemophagocytic Lymphohistiocytosis ${ }^{4}$}

A. Genetic defect consistent with HLH or

B. 5 out of 8 clinical and laboratory criteria

Fever

Splenomegaly

Cytopenia affecting at least 2 peripheral cell lines:

Hemoglobin, $<9 \mathrm{~g} / \mathrm{dL}$

Platelet count, $<100 \times 10^{3} / \mathrm{mL}$

Neutrophil count, $<1 \times 10^{3} / \mu \mathrm{L}$

Hypertriglyceridemia (> $265 \mathrm{mg} / \mathrm{dL}$ ) or hypofibrinogemia (<150 mg/dL)

Hyperferritinemia (> $500 \mathrm{ng} / \mathrm{mL}$ )

Elevated soluble $\mathrm{IL}-2$ receptor level

(>2400 U/mL)

Hemophagocytosis in bone marrow, spleen, or lymph nodes

Low or absent natural killer-cell activity

culture grew Escherichia coli. Given her persistent fever (day 10 of fever) and bacteremia due to gram-negative bacilli, antibiotic coverage was broadened to intravenous cefepime, $50 \mathrm{mg} / \mathrm{kg}$ every 8 hours, and ceftriaxone was discontinued. Doxycycline was discontinued once Rickettsia typhi and Ehrlichia chaffeensis tests returned negative results. Later that day, the patient developed decreased urine output and hyponatremia. She was transferred to the pediatric intensive care unit with concerns for syndrome of inappropriate antidiuretic hormone secretion. A computed tomography scan of the head was unremarkable, and a complete abdominal ultrasonography scan showed mild splenomegaly.

On hospital day 4, repeat laboratory evaluation was significant for leukopenia, anemia, thrombocytopenia, an elevated CRP level, and hyponatremia. Further laboratory parameters revealed hypertriglyceridemia, an elevated ferritin level, a low fibrinogen level, and an elevated soluble interleukin 2 receptor level, which led to suspicion for hemophagocytic lymphohistiocytosis (HLH). A hematologist was consulted, and a presumptive diagnosis of $\mathrm{HLH}$ was considered since the patient had 5 out of 8 criteria (Table 1).

Evaluations for acute infections caused by Epstein-Barr virus, cytomegalovirus, adenovirus, parvovirus, influenza, parainfluenza 1 to 4 , human metapneumovirus, rhinovirus, and arboviruses returned negative results. On hospital day 5, the pathogen causing the patient's bacteremia was identified as Brucella melitensis. Brucella antibodies by agglutination were added to the pre-IVIG serum with a titer of 1:40 (reference range, $<1: 20$ ). Once the diagnosis of brucellosis was established, oral rifampin, $10 \mathrm{mg} / \mathrm{kg}$ every 24 hours and trimethoprim-sulfamethoxazole, 5 $\mathrm{mg} / \mathrm{kg}$ every 12 hours was started, and cefepime was discontinued. Subsequently, the patient improved rapidly. Upon further questioning, the patient's family reported consuming store-bought queso fresco (ie, semisoft fresh cheese) but denied consuming unpasteurized milk or cheese.

\section{Patient Outcome}

At the time of discharge, the patient was afebrile, her conjunctival injection and rash had resolved, and abnormal laboratory parameters were improving. She was discharged home on hospital day 7 to complete a 6-week course of rifampin and trimethoprim-sulfamethoxazole, as well as aspirin. The results of the blood culture from the outside hospital, which returned after the patient's discharge, also grew Brucella melitensis.

The patient followed up with the infectious disease specialist 2 weeks after discharge and was doing well without any complications. A repeat echocardiography scan at 6 weeks post-discharge was unremarkable, and aspirin was discontinued after clearance from a cardiologist. She also followed up with the hematologist, and repeat ferritin, triglyceride, and complete blood cell count tests returned results within the normal range. She completed a course of antibiotics and has had a full recovery.

\section{Discussion}

Brucellosis is a bacterial zoonosis caused by Brucella species, which is an encapsulated Gram-negative coccobacillus. Humans become infected most commonly through consumption of unpasteurized milk or milk products, as well as direct contact with infected animals or aerosol inhalation. It is uncommon in developed countries, and in the United States, 100 to 200 cases of human brucellosis are reported annually. The most common clinical manifestations of brucellosis include fever, fatigue, weight loss, diaphoresis, arthralgia, and myalgia. Complications include spondylitis (most commonly of the lumbar vertebra), genitourinary involvement in boys and men, neurobrucellosis, and endocarditis. Laboratory abnormalities include anemia, thrombocytopenia, or pancytopenia, as well as elevated liver enzyme levels. The diagnosis is established either by positive culture (eg, blood, bone marrow, cerebrospinal fluid, or other bodily fluid) or detection of specific antibodies or nucleic amplification detection plus compatible clinical picture. ${ }^{2}$ Of note serologic tests should not be used alone for diagnosis because of crossreactivity with other bacteria, false-negative results in some cases, and persistently positive results even after treatment. ${ }^{3}$ In children, treatment duration is 6 to 8 weeks and includes doxycycline plus rifampin in children older than 8 years or trimethoprim-sulfamethoxazole plus rifampin in children younger than 8 years. ${ }^{2}$

$\mathrm{HLH}$ is a rare disease, which usually occurs in infants and children. According to the Histocyte Society HLH-2004 study, the diagnosis is made if 5 of 8 criteria are fulfilled (Table 1). ${ }^{4}$ Historically, HLH has been categorized as primary (hereditary) or secondary (triggered by autoimmune diseases, malignancy, or infection). ${ }^{5}$ The most common infections causing secondary HLH are viral infections, namely 
Epstein-Barr virus. HLH-specific therapy is aimed at decreasing hyperinflammation with dexamethasone and etoposide. ${ }^{4,5}$ Other reported treatments include IVIG, plasma exchange, and anakinra. ${ }^{5}$

There has been discussion in the literature about reconceptualizing $\mathrm{HLH}$ to aid in the decision-making process as well as in prompt initiation of HLH-directed therapies. One proposal is the use of the umbrella term "HLH syndrome" for conditions meeting diagnostic criteria. The umbrella term would include: ${ }^{6}$

HLH disease: Patients who would benefit from $\mathrm{HLH}$-specific therapies

HLH disease mimics: Patients in whom distinctive immune dysregulation is not the core problem and thus would not benefit from immune suppression but rather treatment of the underlying condition

A PubMed search and review of case reports of pediatric brucellosis and HLH in the literature mainly occur in areas of the world where brucella is endemic or in patients who recently visited such areas (Table 2). ${ }^{7-17}$ Many of these patients underwent invasive procedures (such as bone marrow biopsy) to complete $\mathrm{HLH}$ evaluation, and some received HLH-directed treatment, despite most patients improving quickly on antibiotics alone. We believe that in those cases where brucella and HLH disease mimics are suspected, a cautious approach should be taken, and invasive procedures and $\mathrm{HLH}$-directed treatment should be deferred if the patient remains stable.

A challenging aspect of the diagnosis is the slow-growing nature of brucella, leading to a delay in diagnosis, especially in regions of low endemicity. Another challenge is when to suspect $\mathrm{HLH}$ disease mimics vs HLH disease. A retrospective study conducted at our institution investigated hyperferritinemia and $\mathrm{HLH}$ and revealed that a ferritin level of more than $10,000 \mu \mathrm{g} / \mathrm{L}$ was $90 \%$ sensitive and $96 \%$ specific for HLH disease. ${ }^{18}$ In that study, 330 patients had ferritin levels higher than $500 \mu \mathrm{g} / \mathrm{L}$. Of the 330 patients, 10 were diagnosed with $\mathrm{HLH}$ disease and had a median ferritin level of $5992 \mu \mathrm{g} / \mathrm{L}$ (range, 757-63,919 $\mu \mathrm{g} / \mathrm{L}$ ). Interestingly, 43 patients had bacterial infections and had a median ferritin level of $943 \mu \mathrm{g} / \mathrm{L}$ (range, 523-7508 $\mu \mathrm{g} / \mathrm{L}$ ). We propose that it is reasonable to suspect HLH disease mimics and to avoid unnecessary invasive procedures and treatments in individuals with modest increases in ferritin level and in whom there is suspicion for an infectious etiology if they are clinically stable.

Our patient would best fit into the category of HLH disease mimics due to brucellosis. It is possible that treatment with IVIG could have modified her course somewhat, but she recovered without undergoing any invasive procedures or HLH-directed therapy. Also, our patient's ferritin level was $1390 \mu \mathrm{g} / \mathrm{L}$ on presentation, which correlates with the median range for ferritin levels in patients with a bacterial infection in the study performed at our institution..$^{18}$ More prospective studies are needed to better elucidate the difference between HLH disease and $\mathrm{HLH}$ disease mimics to direct appropriate management and therapy as promptly as possible.

In a patient like ours who presents with fever, rash, transaminitis, hepatosplenomegaly, and cytopenias, it is important to initiate a systematic approach to ruling out other diseases such as Kawasaki disease, viral infections, rickettsial diseases, bacterial infections, malignancies, and rheumatological processes including MIS-C. HLH disease mimics should also be in the differential diagnosis while awaiting diagnostic tests.

\section{Conclusions}

Brucellosis is a bacterial zoonotic disease that can lead to HLH disease mimics. A careful history, physical examination, and a thorough laboratory evaluation would enable physicians to diagnose this disease. Lack of exposure to unpasteurized milk products or farm animals should not dissuade a clinician from suspecting brucellosis. Prompt initiation of antibiotics is important for early recovery and avoid- ance of further invasive procedures and unwarranted $\mathrm{HLH}$-directed therapy.

\section{References}

1. Pappas G, Papadimitriou P, Akritidis N, Christou L, Tsianos EV. The new global map of human brucellosis. Lancet Infect Dis. 2006;6(2):91-99. https://doi.org/10.1016/ s1473-3099(06)70382-6

2. Bukhari EE. Pediatric brucellosis. An update review for the new millennium. Saudi Med J. 2018;39(4):336-341. https://doi. org/10.15537/smj.2018.4.21896

3. Pappas G, Akritidis N, Bosilkovski M, Tsianos E. Brucellosis. N Engl J Med. 2005;352:2325-36. https://www.nejm.org/ doi/full/10.1056/NEJMra050570

4. Henter Jl, Horne A, Aricó $M$, et al. HLH-2004: Diagnostic and therapeutic guidelines for hemophagocytic lymphohistiocytosis. Pediatr Blood Cancer. 2007;48(2):124-131. https://doi.org/10.1002/ pbc.21039

5. Canna SW, Marsh RA. Pediatric hemophagocytic lymphohistiocytosis Blood. 2020;135(16):1332-1343. https://doi. org/10.1182/blood.2019000936

6. Jordan MB, Allen CE, Greenberg J, et al. Challenges in the diagnosis of hemophagocytic lymphohistiocytosis: recommendations from the North American Consortium for Histiocytosis (NACHO). Pediatr Blood Cancer. 2019;66(11):e27929. https://doi. org/10.1002/pbc.27929

7. Yaman Y, Gözmen S, Özkaya AK, et al. Secondary hemophagocytic lymphohistiocytosis in children with brucellosis: report of three cases. J Infect Dev Ctries. 2015;9(10):1172-1176. https://doi. org/10.3855/jidc.6090

8. Karaman K, Akbayram S, Kaba S, et al. An analysis of children with brucellosis associated with haemophagocytic lymphohistiocytosis. Infez Med. 2016;24(2):123-130. https://www.infezmed.it/media/journal/ Vol_24_2_2016_4.pdf

9. Pekpak E, Sirvan Cetin B. Secondary hemophagocytic lymphohistocytosis in a child with brucellosis. J Pediatr Hematol Oncol. 2017;39(8):e501-e503. https://doi. org/10.1097/mph.0000000000000849

10. Erduran E, Makuloglu M, Mutlu M. A rare 
Table 2. A Review of the Literature of Pediatric Brucellosis and Hemophagocytic Lymphohistiocytosis

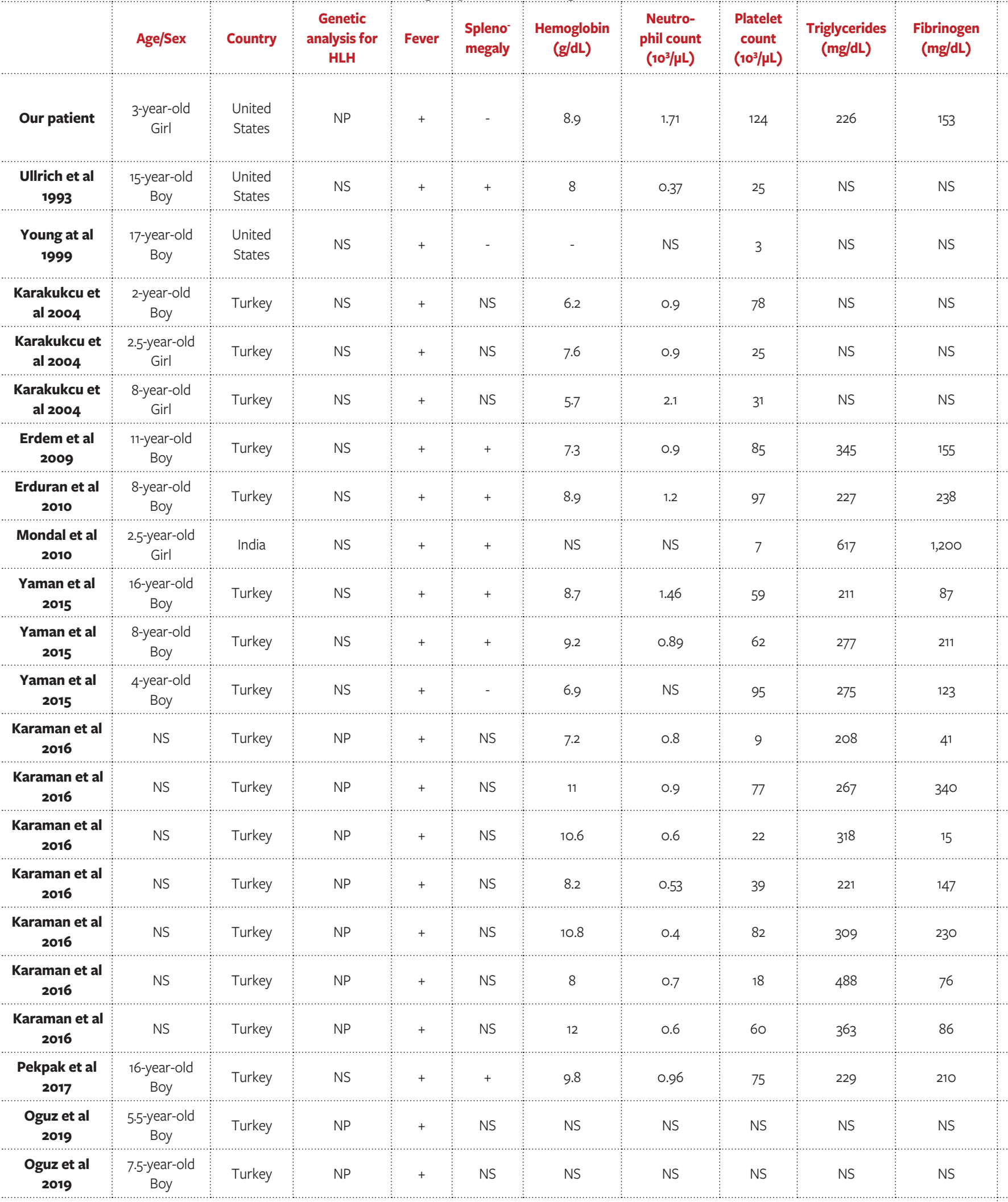

NS = not specified; NP = not performed; IVIG = intravenous immunoglobin; RMP = rifampin; doxy = doxycycline; dex = dexamethasone; TCN = tetracycline; gent = gentamycin; TXA = tranexamic acid; TMP-SMX = trimethoprim-sulfamethoxazole; FFP = fresh frozen plasma 
Table 2. A Review of the Literature of Pediatric Brucellosis and Hemophagocytic Lymphohistiocytosis (continued)

\begin{tabular}{|c|c|c|c|c|c|c|c|}
\hline $\begin{array}{l}\text { Ferritin (ng/ } \\
\mathrm{mL})\end{array}$ & $\begin{array}{l}\text { Soluble IL-2 } \\
\text { receptor } \\
\text { level }(\mathrm{U} / \mathrm{mL})\end{array}$ & $\begin{array}{l}\text { Natural killer } \\
\text { cell activity }\end{array}$ & $\begin{array}{l}\text { Hmo-phagocy- } \\
\text { tosis in bone } \\
\text { marrow }\end{array}$ & Brucella culture positive & $\begin{array}{l}\text { Serology } \\
\text { titers }\end{array}$ & Treatment & Outcome \\
\hline 676 & 2652 & NP & NP & B melitensis in blood & $1: 40$ & $\begin{array}{l}\text { RMP, TMP-SMX } \\
\text { IVIG (given for } \\
\text { KD) }\end{array}$ & $\begin{array}{l}\text { Completely } \\
\text { recovered }\end{array}$ \\
\hline NS & NS & NS & + & $\begin{array}{l}\text { B melitensis in blood and bone } \\
\text { marrow }\end{array}$ & 1:5120 & TCN, gent, doxy & $\begin{array}{l}\text { Completely } \\
\text { recovered }\end{array}$ \\
\hline NS & NS & NS & - & $\mathrm{B}$ melitensis in bone marrow & $1: 320$ & $\begin{array}{c}\text { Doxy, gent, TMP- } \\
\text { SMX, FFP, TXA, } \\
\text { dex }\end{array}$ & Died \\
\hline NS & NS & NS & + & NS & NS & Antibiotics NS & $\begin{array}{l}\text { Completely } \\
\text { recovered }\end{array}$ \\
\hline NS & NS & NS & + & NS & NS & Antibiotics NS & $\begin{array}{l}\text { Completely } \\
\text { recovered }\end{array}$ \\
\hline NS & NS & NS & + & NS & NS & Antibiotics NS & $\begin{array}{l}\text { Completely } \\
\text { recovered }\end{array}$ \\
\hline 3167 & NS & NS & + & Blood and bone marrow sterile & $1: 2560$ & Doxy, gent & $\begin{array}{l}\text { Completely } \\
\text { recovered }\end{array}$ \\
\hline 1243 & NS & NS & + & Blood and bone marrow sterile & $1: 640$ & RMP, TMP-SMX & $\begin{array}{l}\text { Completely } \\
\text { recovered }\end{array}$ \\
\hline$>1500$ & - & - & + & $\mathrm{B}$ melitensis in bone marrow & 1:1282 & RMP, TMP-SMX & $\begin{array}{l}\text { Completely } \\
\text { recovered }\end{array}$ \\
\hline 1650 & NS & NS & + & $\begin{array}{l}\text { Brucella in blood and bone } \\
\text { marrow }\end{array}$ & $1: 640$ & RMP, doxy, IVIG & $\begin{array}{l}\text { Completely } \\
\text { recovered }\end{array}$ \\
\hline 543 & NS & NS & + & $\begin{array}{l}\text { Brucella in blood and bone } \\
\text { marrow }\end{array}$ & $1: 2560$ & RMP, doxy, IVIG & $\begin{array}{l}\text { Completely } \\
\text { recovered }\end{array}$ \\
\hline 11,173 & NS & NS & + & Brucella in blood & $1: 320$ & $\begin{array}{l}\text { RMP, gent, doxy, } \\
\text { IVIG }\end{array}$ & $\begin{array}{l}\text { Completely } \\
\text { recovered }\end{array}$ \\
\hline 17,429 & NS & NS & - & $\begin{array}{l}\text { B melitensis in blood and bone } \\
\text { marrow }\end{array}$ & $1: 1280$ & Antibiotics NS & $\begin{array}{l}\text { Completely } \\
\text { recovered }\end{array}$ \\
\hline 856 & NS & NS & + & $\begin{array}{l}\text { B melitensis in blood and bone } \\
\text { marrow }\end{array}$ & $1: 1280$ & Antibiotics NS & $\begin{array}{l}\text { Completely } \\
\text { recovered }\end{array}$ \\
\hline 1952 & NS & NS & + & B melitensis in bone marrow & $1: 1280$ & Antibiotics NS & $\begin{array}{l}\text { Completely } \\
\text { recovered }\end{array}$ \\
\hline 4050 & NS & NS & + & Blood and bone marrow sterile & $1: 1280$ & Antibiotics NS & $\begin{array}{l}\text { Completely } \\
\text { recovered }\end{array}$ \\
\hline 6700 & NS & NS & - & Blood and bone marrow sterile & $1: 1280$ & Antibiotics NS & $\begin{array}{l}\text { Completely } \\
\text { recovered }\end{array}$ \\
\hline 4500 & NS & NS & + & $\begin{array}{l}\text { B melitensis in blood and bone } \\
\text { marrow }\end{array}$ & $1: 1280$ & Antibiotics NS & $\begin{array}{l}\text { Completely } \\
\text { recovered }\end{array}$ \\
\hline 6940 & NS & NS & + & Blood and bone marrow sterile & $1: 1280$ & Antibiotics NS & $\begin{array}{l}\text { Completely } \\
\text { recovered }\end{array}$ \\
\hline 4104 & NS & NS & + & $\begin{array}{l}\text { Brucella in blood and bone } \\
\text { marrow }\end{array}$ & $1: 1280$ & $\begin{array}{l}\text { RMP, doxy, dex, } \\
\text { IVIG }\end{array}$ & $\begin{array}{c}\text { Completely } \\
\text { recovered }\end{array}$ \\
\hline NS & NS & NS & NS & Brucella in blood & $\begin{array}{l}\text { Positive } \\
\text { titer NS }\end{array}$ & Antibiotics NS & $\begin{array}{l}\text { Completely } \\
\text { recovered }\end{array}$ \\
\hline NS & NS & NS & NS & Brucella in blood & $\begin{array}{l}\text { Positive } \\
\text { titer NS }\end{array}$ & Antibiotics NS & $\begin{array}{l}\text { Completely } \\
\text { recovered }\end{array}$ \\
\hline
\end{tabular}

$\mathrm{NS}=$ not specified; NP = not performed; IVIG = intravenous immunoglobin; RMP = rifampin; doxy = doxycycline; dex = dexamethasone; $\mathrm{TCN}=$ tetracycline; gent = gentamycin; TXA = tranexamic acid; TMP-SMX = trimethoprim-sulfamethoxazole; FFP = fresh frozen plasma 


\section{CASE IN POINT}

hematological manifestation of brucellosis: reactive hemophagocytic syndrome. $J$ Microbiol Immunol Infect. 2010;43(2):159162. https://doi.org/10.1016/s16841182(10)60025-4

11. Mondal N, Suresh R, Acharya NS, Praharaj I, Harish BN, Mahadevan S. Hemophagocytic syndrome in a child with brucellosis. Indian J Pediatr. 2010;77(12):1434-1436. https://doi.org/10.1007/s12098-010-0221-z

12. Karakukcu M, Patiroglu T, Ozdemir MA, Gunes T, Gumus H, Karakukcu C. Pancytopenia, a rare hematologic manifestation of brucellosis in children. J Pediatr Hematol Oncol. 2004;26(12):803-806. https://journals.Iww.com/jpho-online/Abstract/2004/12000/Pancytopenia,_a_Rare_ Hematologic_Manifestation_of.5.aspx

13. Young EJ, Tarry A, Genta RM, Ayden N, Gotuzzo E. Thrombocytopenic purpura associated with brucellosis: report of 2 cases and literature review. Clin Infect Dis. 2000;31(4):904-909. https://doi. org/10.1086/318129

14. Erdem E, Yıldırmak Y, Günaydın N. Brucellosis presenting with pancytopenia due to hemophagocytic syndrome. Turk J Haematol. 2011;28(1):68-71. https://doi.org/10.5152/ tjh.2011.09

15. Oguz MM, Sahin G, Altinel Acoglu E, et al. Secondary hemophagocytic lymphohistiocytosis in pediatric patients: a single center experience and factors that influenced patient prognosis. Pediatr Hematol Oncol. 2019;36(1):1-16. https://doi.org/10.1080/088 80018.2019.1572253

16. Akbayram S, Dogan M, Akgun C, Peker E, Parlak M, Oner AF. An analysis of children with brucellosis associated with isolated thrombocytopenia. Clin Appl Thromb Hemost. 2011;17(6):E36-E38. https://doi. org/10.1177/1076029610382104

17. Ullrich $\mathrm{CH}$, Fader $\mathrm{R}$, Fahner JB, Barbour SD. Brucellosis presenting as prolonged fever andhemophagocytosis. Am J Dis Child. 1993;147(10):1037-1038. doi:10.1001/archpedi.1993.02160340023005

18. Allen CE, Yu X, Kozinetz CA, McClain KL. Highly elevated ferritin levels and the diagnosis of hemophagocytic lymphohistiocytosis. Pediatr Blood Cancer. 2008;50(6):12271235. https://doi.org/10.1002/pbc. 21423 